\title{
Decreased Insulin Response to Glucose in Islet Cell Antibody- Negative Siblings of Type 1 Diabetic Children
}

\author{
Jean-Claude Carel, * Christian Boitard, ${ }^{\star}$ and Pierre-François Bougnères * \\ * René Descartes University, Institut National de la Sante et de la Recherche Medicale U342 and Pediatric Endocrinology, \\ St. Vincent de Paul Hospital; and ${ }^{\ddagger}$ Clinical Immunology, Necker Hospital, Paris, France
}

\begin{abstract}
Measurement of $\beta$-cell function is an important marker of progression to diabetes in individuals at risk for the disease. Although the peak incidence for the disease occurs before 17 years of age, normal values for insulin secretion were not available in this age group. We performed a simplified intravenous glucose tolerance test in 167 normal children, and in 98 islet cell antibody (ICA)-negative and 12 ICA-positive siblings of diabetic patients. Their age range was 1-16 yr. The first phase of insulin secretion, evaluated as the sum of plasma insulin concentrations at 1 and $3 \mathrm{~min}$, increased with age and was significantly lower in ICA-negative siblings $(86 \pm 6 \mu \mathrm{U} / \mathrm{ml}, P$ $<0.002)$ than in normal controls $(115 \pm 6 \mu \mathrm{U} / \mathrm{ml})$. This difference was not apparent before $8 \mathrm{yr}$ of age. None of the ICA-negative siblings developed diabetes after an average of $4.5 \mathrm{yr}$. ICA-positive siblings at first study had a first phase insulin response similar to that of ICA negative siblings, but signifcantly lower than that of the normal controls $(74 \pm 13 \mu \mathrm{U} / \mathrm{ml}, P$ $<0.02)$. The reason for the decreased insulin secretion in ICAnegative siblings is unknown, but could involve a defect in the growth of $\beta$-cell mass or insulin secretion that could be part of the multifactorial pathogenesis of type 1 diabetes. (J. Clin. Invest. 1993. 92:509-513.) Key words: insulin secretion • $\beta$-cell function • pre-type 1 diabetes
\end{abstract}

\section{Introduction}

As reflected by the incidence peak of its clinical onset between 7 and 17 yr of age $(1,2)$, type 1 diabetes results from the loss of insulin secretion during childhood and preadolescence. The failure of $\beta$-cell function is a consequence of the lymphocytic infiltration of the islets of Langerhans leading to the autoimmune destruction of insulin-secreting cells (3). First degree relatives of type 1 diabetic patients are at increased risk for the disease and the presence of antibodies reacting with various $\beta$-cell antigens is predictive of diabetes in this population (46 ). In the individuals who progress to diabetes, the gradual

Address reprint requests to $P$. F. Bougnères, Pediatric Endocrinology, Hôpital Saint Vincent de Paul, 82 Avenue Denfert-Rochereau, 75014 Paris, France.

Received for publication 31 December 1992 and in revised form 8 March 1993.

J. Clin. Invest.

(c) The American Society for Clinical Investigation, Inc.

0021-9738/93/07/0509/05 \$2.00

Volume 92, July 1993, 509-513 decline of insulin secretion is believed to be due to the destruction of $\beta$ cells by insulitis as seen in autoimmune animal models (3).

Various degree of glucose intolerance have been reported in siblings or twins of diabetic patients (7-11). These abnormalities of glucose homeostasis affected more siblings than the proportion expected to progress to diabetes (12).

A reduction of insulin response to intravenous glucose has also been reported in first degree relatives of diabetic patients $(13,14)$. These studies, however, were performed at a time when the autoimmune status could not be tested. More recently, the study of a small group of islet cell antibody (ICA $)^{1}$-negative HLA-identical adult siblings of type 1 diabetic patients revealed a decrease of both insulin sensitivity and first phase insulin response to glucose $(15,16)$. These observations, as well as the increased incidence of non-insulin-dependent diabetes (NIDDM) in families of young type 1 diabetics $(17,18)$, suggest that nonautoimmune alterations of insulin secretion may be part of the complex genetics of the disease and prompted us to reevaluate insulin secretion in siblings of diabetic children. Another incentive for undertaking this study is the recent linkage to type 1 diabetes of genotypic markers localized in the vicinity of the insulin gene on chromosome 11 (19), although there is no indication yet that this could be related to alterations of insulin gene transcription.

To be able to interpret our data, we had to acquire information regarding normal insulin secretion during childhood and adolescence. Such data are, to our knowledge, only available for adult normal controls (20). In fact, all studies of insulin secretion and sensitivity in prepubertal and pubertal children have been performed in ICA-negative first degree relatives of type 1 diabetic patients (21-24), none in normal children. To make our investigation acceptable to large numbers of healthy children, we performed a simplified intravenous glucose tolerance test, considered a reliable predictor of $\beta$-cell dysfunction in pre-type 1 diabetes (25).

\section{Methods}

Subjects. From 1986 to 1992, we recruited 110 siblings of type 1 diabetic children followed at our center. Their age ranged from 1 to $16.5 \mathrm{yr}$ at time of testing, which included detection of islet cell antibodies, insulin autoantibodies, and insulin response to intravenous glucose. They were separated into two groups according to the presence of antibodies: 98 siblings were found negative for either class of antibodies

1. Abbreviations used in this paper: ICA, islet cell antibody; NIDDM, non-insulin-dependent diabetes mellitus. 
and 12 positive for islet cell antibodies \pm insulin antibodies. All children were in good health at time of testing.

We studied for comparison 167 normal children aged 3.2 to $15 \mathrm{yr}$, selected among the investigators', colleagues', nurses', and friends' families $(91 / 167)$, as well as among patients $(76 / 167)$ hospitalized for reasons not interfering with insulin and glucose homeostasis (benign surgery, evaluation of familial mild short stature, or isolated cryptorchidism). In all children, sexual maturation was consistent with chronological age, and physical examination was normal except for the aforementioned abnormalities. Subjects with a familial history of type 1 or 2 diabetes, gestational diabetes, or abnormally high birth weights were systematically excluded. Body wt had to be within $90-110 \%$ of ideal body wt for age.

Informed consent was obtained from the parents and the children, after the investigative nature of our research had been explained, according to principles approved by INSERM Committee on Medical Bioethics.

The characteristics of the children studied are presented in Table I.

Procedures. During the $3 \mathrm{~d}$ preceding insulin measurements, the children were prescribed a standardized diet, containing 1000 calories, plus an additional 100 calories/yr of age, and $50 \%$ carbohydrates, based on the eating habits of French children (26). Parents or nurses checked the observance of the diet, and children with poor appetites and insufficient intakes (less than $75 \%$ of prescribed carbohydrates) were excluded.

Children were fasted $12 \mathrm{~h}$ overnight, from the end of dinner (2000 hours) to time 0 of the test ( 0800 hours). They slept normally and were studied after $1 \mathrm{~h}$ of normal ambulatory activity. To avoid the effect of vein puncture stress, we inserted an intravenous line in a superficial brachial vein of each arm $1 \mathrm{~h}$ before time 0 .

A dose of $0.5 \mathrm{mg}$ glucose $/ \mathrm{kg}$ body wt ( $50 \%$ dextrose) was manually injected in $2.5 \mathrm{~min}$, with an average precision of $\pm 5 \mathrm{~s}$. Time zero was taken at the end of the intravenous bolus. Blood samples were collected from the opposite arm at 1 and $3 \mathrm{~min}$ for measurements of insulin. In hospitalized patients, the venous lines were subsequently used for other medical purposes independent of this investigation.

Analytical methods. Plasma insulin concentration was measured with a radioimmunoassay (Oris; CEA Instruments, Inc., Emerson, $\mathrm{NJ}$ ) having an average relative precision of $12 \%$ within a $18-60 \mathrm{pmol} /$ liter range and $8 \%$ within a $60-1200 \mathrm{pmol} /$ liter range. During the period of study, the technique was periodically calibrated using an insulin standard from Novo Nordisk (Bagsvaerd, Denmark).

To compare our pediatric values with those previously reported in normal adults (20), our technique (SVP) was examined with regard to that used at the Joslin Clinic in Boston $(\mathrm{J})$. The linear relationship between the two centers showed close correlation $(r=0.99)$ and was described by the following equation: (insulin) $)_{\mathbf{J}}=1.6$ (insulin $)_{\mathbf{S v P}}$ -1.54 .

As.the majority of techniques used for measuring insulin in clinical studies, our radioassay cross-reacted with proinsulin, so $80-85 \%$ of the observed value actually represent insulin. This value was obtained by comparing our results with those obtained using a double antibody technique, eliminating cross-reactivity with proinsulin (courtesy of Dr. R. Djurup, Novo Nordisk.

Islet cell antibodies were detected according to the methods and score included in the Fourth International Diabetes Workshop analysis, with a threshold of $2.5 \mathrm{JDF}$ units (27). Antiinsulin antibodies were measured using a previously reported radioassay (28).

Statistics. Simple linear regression was used to describe the relationship between parameters. Student's $t$ test for unpaired variables allowed comparison between groups.

\section{Results}

In all children, fasting plasma glucose was normal (Table I) with respect to the National Diabetes Data Group criteria (29).
Insulin response, expressed as the sum of the insulin measurements at 1 and $3 \mathrm{~min}$, correlated with age, both in normal children and in ICA-negative siblings ( Fig. 1). Insulin response to intravenous glucose was decreased by approximately $25 \%$ in the group of 98 ICA-negative siblings compared with the control children $(P<0.002$, Table I $)$. The slope of the regression line describing the relationship between age and insulin secretion was $42 \%$ steeper in the controls than in the siblings. When the children were stratified arbitrarily with respect to the median of their age, we did not detect any significant difference of insulin values between ICA-negative siblings and normal children under the age of $8 \mathrm{yr}$ (Table II).

23 siblings had insulin responses under the lower agematched normal values and were analyzed separately ( Table I) 16 of them were clustered in 6 families. None of them developed diabetes during follow-up. The incidence of type 2 diabetes was increased in families of type 1 diabetic patients $(27 \%$ of families) compared with $1.4 \%$ of individuals of the general population ( 30 ), but this trend was not different in the group of siblings with the lowest insulin responses.

The 12 ICA-positive siblings had insulin $1+3 \mathrm{~min}$ responses averaging $74 \pm 13 \mu \mathrm{U} / \mathrm{ml}(P<0.02$ vs. controls $)$ at first testing, a value comparable with that of the ICA-negative siblings. At their last testing, $29 \pm 5$ mo later, 9 of 12 had a mean value of $67 \pm 17 \mu \mathrm{U} / \mathrm{ml}$, statistically not different from first testing. Two became diabetic, and one was not retested.

One of the children of the present study, followed from 1986 to 1992 , consistently showed low insulin responses at $3 \mathrm{yr}$ of age $(20 \mu \mathrm{U} / \mathrm{ml}), 4 \mathrm{yr}(36 \mu \mathrm{U} / \mathrm{ml})$, and $9 \mathrm{yr}(83 \mu \mathrm{U} / \mathrm{ml})$, while he converted to islet cell antibody positivity (20-40 JDFU) at 4 yr. This child has a diabetic brother, who developed the clinical disease at 8.9 yr. Two other siblings were ICA negative and low insulin responders with $1+3 \mathrm{~min}$ insulin values of 36 and $50 \mu \mathrm{U} / \mathrm{ml}$ at $7 \mathrm{yr}$ of age.

\section{Discussion}

The present results were unexpected, since the diminution and loss of insulin secretion in type 1 diabetes was considered exclusively the consequence of an autoimmune attack of the $\beta$ cells. In fact, the high frequency of glucose intolerance in siblings of diabetic patients $(9,10)$, the observations made by the Seattle group $(15,16)$, and the increased proinsulin levels in ICA-negative siblings of patients ( 31 ) already suggested the existence of a $\beta$ cell dysfunction in families of type 1 diabetic patients. Our study in a large cohort of siblings is consistent with these observations and leads to several working hypotheses.

A genetically determined nonautoimmune intrinsic defect of $\beta$ cell function or reduction of $\beta$ cell mass may exist in type 1 diabetes. Genetic susceptibility to type 1 diabetes involves 3 and probably more genes ( 32 ). One of the susceptibility genes could be implicated in insulin secretion or growth of $\beta$-cell mass and account for its decrease in nondiabetic siblings. In the human, only the MHC and the insulin-IGF I region have yet been implicated $(19,32)$. A susceptibility gene close or within the MHC is unlikely to explain our observation, since in other studies no correlation was found between HLA haplotype sharing and insulin secretion (33) or proinsulin levels (31) in siblings of diabetic patients. Since an inverse relationship was recently found between insulin secretion and serum $\operatorname{Lp}(a)$ levels in healthy adults (34), it will be interesting to test the link 
Table I. Insulin Secretion in Response to Intravenous Glucose in Children from Nondiabetic Families and in Siblings of Type 1 Diabetic Children

\begin{tabular}{|c|c|c|c|c|}
\hline & \multirow[b]{3}{*}{$\begin{array}{c}\text { Children from } \\
\text { nondiabetic families }\end{array}$} & \multicolumn{3}{|c|}{ Siblings of type 1 diabetic children } \\
\hline & & \multirow[b]{2}{*}{$\mathrm{ICA}+$} & \multicolumn{2}{|c|}{ ICA - } \\
\hline & & & All & Low responders \\
\hline No. of subjects & 167 & 12 & 98 & 23 \\
\hline No. of families & 165 & 12 & 84 & 13 \\
\hline Age at test (yr) & $9.8 \pm 0.3$ & $6.1 \pm 1.0$ & $9.3 \pm 0.4$ & $10.5 \pm 0.7$ \\
\hline BMI $\left(\mathrm{kg} / \mathrm{m}^{2}\right)$ & $16.5 \pm 0.1$ & $16.4 \pm 0.1$ & $16.5 \pm 0.1$ & $16.1 \pm 0.3$ \\
\hline Age of onset of diabetes in sib (yr) & - & $9.1 \pm 1$ & $9.3 \pm 1$ & $9.2 \pm 1.3$ \\
\hline$\%$ families with NIDDM & 0 & 0 & 27 & 26 \\
\hline Follow-up (yr) & $4.4 \pm 0.8$ & $2.4 \pm 0.4$ & $4.4 \pm 1.2$ & $4.5 \pm 1.1$ \\
\hline IDDM occurrence & 0 & 2 & 0 & 0 \\
\hline \multicolumn{5}{|l|}{$\begin{array}{l}\text { Plasma insulin after intravenous } \\
\text { glucose }\end{array}$} \\
\hline $1+3 \mathrm{~min}$ insulin $(\mu \mathrm{U} / \mathrm{ml})$ & $115 \pm 6$ & $74 \pm 13^{*}$ & $86 \pm 6^{\ddagger}$ & $37 \pm 2$ \\
\hline \multicolumn{5}{|l|}{$1+3 \mathrm{~min}$ insulin/body surface } \\
\hline$\left(\mu \mathrm{U} / \mathrm{m}^{2}\right)$ & $113 \pm 5$ & $86 \pm 14^{*}$ & $85 \pm 6^{\S}$ & $38 \pm 1.9$ \\
\hline \multicolumn{5}{|l|}{$1+3 \mathrm{~min}$ insulin/body mass } \\
\hline index $\left(\mu \mathrm{U}^{*} \mathrm{~m}^{2} / \mathrm{kg}\right)$ & $6.9 \pm 0.3$ & $5.2 \pm 0.8^{*}$ & $5.2 \pm 0.4^{\ddagger}$ & $2.3 \pm 0.1$ \\
\hline Fasting plasma glucose $(\mathrm{mmol} / \mathrm{l})$ & $4.6 \pm 0.1$ & $4.5 \pm 0.1$ & $4.5 \pm 0.1$ & $4.6 \pm 0.1$ \\
\hline
\end{tabular}

Type 2 diabetes in second- or third-degree relatives of the diabetic patient defined families with NIDDM. ${ }^{*} P<0.025 ;{ }^{\ddagger} P<0.002 ;{ }^{\S} P<0.001$ vs. values in children from nondiabetic families.

between genetic factors determining $\mathrm{Lp}(\mathrm{a})$ levels and diabetes mellitus. The defect of insulin secretion is apparently not sufficient per se to induce juvenile diabetes mellitus in the short term since none of the 23 children with the lowest insulin response developed diabetes after a mean follow-up of $4.5 \pm 1.1$ years. This is consistent with the observation that the onset of type 1 diabetes in children is almost constantly associated with the presence of circulating autoantibodies (35).
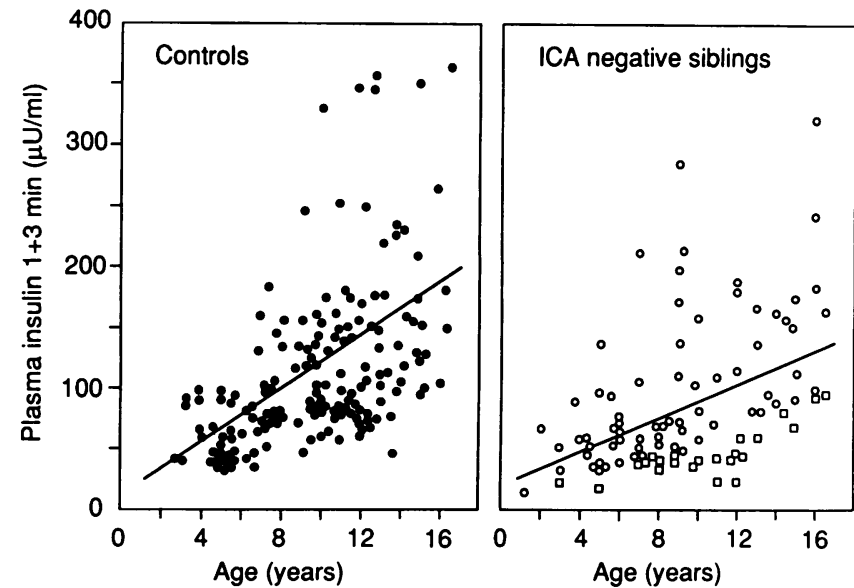

Figure 1. Relationship between age and the first phase insulin secretion to intravenous glucose in normal controls $(\bullet)$ and in ICA-negative first-degree relatives of type 1 diabetic children $(O$ and $\square) ; \square, 23$ children with values inferior to those of normal controls. The equations for the regression lines are: $Y=10.5 X+11.3(r=0.46, P$ $<0.0001)$ for the normal children, and $Y=6.1 X+30(r=0.39, P$ $<0.0025$ ) for the ICA-negative siblings.
On the basis of our observation, it is interesting to speculate that a fraction of ICA-negative insulin-dependent diabetes that start in adulthood are possibly related to nonautoimmune insulin deficiency. Approximately $20-30 \%$ of recent type 1 diabetic adults do not have circulating autoantibodies (35) and the HLA subtypes predisposing to autoimmune diabetes are less prevalent in adult than in pediatric cases of type 1 diabetes (36).

A genetic defect of insulin secretion could also explain the interference of non-insulin-dependent (type 2) with type 1 diabetes in these families. However, we did not find an increased frequency of type 2 diabetes in the families of individuals with the lowest insulin responses.

Although this has not been studied in man, it is possible that insulin secretion or $\beta$-cell mass are influenced by dietary carbohydrates. In this respect, our observation could be the result of a reduced carbohydrate intake in the brothers and sisters of type 1 diabetic patients. We do not favor this hypothesis because the diet in our diabetic population is comparable to that of normal children (37). In addition, short-term nutrition was carefully standardized in the siblings and in the controls during the $3 \mathrm{~d}$ preceding the test.

Another possibility is that the autoimmune attack of insulin-secreting cells progresses slowly in a subset of siblings, without evidence of circulating antibodies. Alternatively, a remittingly destructive insulitis may reduce the insulin secretory response or $\beta$-cell mass in a subset of ICA-negative siblings without progressing to complete failure (38).

This study provides new information on insulin secretion in normal children. As observed previously in ICA-negative siblings of diabetic patients $(23,24,39)$, this study confirms that the first phase of insulin secretion increases markedly with 
Table II. Insulin Secretion in Response to Intravenous Glucose in Children from Nondiabetic Families and ICA-negative Siblings of Type 1 Diabetic Children

\begin{tabular}{|c|c|c|c|c|}
\hline & \multicolumn{2}{|c|}{$\leq 8 \mathrm{yr}$} & \multicolumn{2}{|c|}{$>8 \mathrm{yr}$} \\
\hline & $\begin{array}{l}\text { Children from } \\
\text { non-diabetic families }\end{array}$ & $\begin{array}{l}\text { ICA-negative } \\
\text { siblings of type } 1 \\
\text { diabetic patients }\end{array}$ & $\begin{array}{l}\text { Children from } \\
\text { non-diabetic families }\end{array}$ & $\begin{array}{c}\text { ICA-negative } \\
\text { siblings of type } 1 \\
\text { diabetic patients }\end{array}$ \\
\hline$n$ & 56 & 40 & 111 & 58 \\
\hline Age (yr) & $6 \pm 0.2$ & $5.6 \pm 0.3$ & $11.9 \pm 0.2$ & $11.9 \pm 0.3$ \\
\hline \multicolumn{5}{|l|}{$\begin{array}{l}\text { Plasma insulin after intravenous } \\
\text { glucose }\end{array}$} \\
\hline $1+3 \mathrm{~min}$ insulin $(\mu \mathrm{U} / \mathrm{ml})$ & $73 \pm 5$ & $68 \pm 9$ & $136 \pm 8$ & $99 \pm 8^{*}$ \\
\hline \multicolumn{5}{|l|}{$1+3 \mathrm{~min}$ insulin/body } \\
\hline surface $\left(\mu \mathrm{U} / \mathrm{m}^{2}\right)$ & $96 \pm 6$ & $89 \pm 11$ & $121 \pm 7$ & $82 \pm 7^{\ddagger}$ \\
\hline \multicolumn{5}{|l|}{$1+3 \mathrm{~min}$ insulin/body mass } \\
\hline index $\left(\mu \mathrm{U}^{*} \mathrm{~m}^{2} / \mathrm{kg}\right)$ & $4.8 \pm 0.3$ & $4.4 \pm 0.6$ & $8.0 \pm 0.5$ & $5.7 \pm 0.7^{*}$ \\
\hline
\end{tabular}

The values are subdivided according to age at time of testing. ${ }^{*} P<0.005,{ }^{\ddagger} P<0.001$ vs. children from nondiabetic families.

age, with a maximum at time of puberty, when insulin sensitivity is minimal $(21,22)$. The interpretation of a low insulin response to glucose in an ICA-positive child should take into account the age-matched values in controls as well as in ICAnegative siblings.

In summary, this study reveals a decreased insulin response to glucose in ICA negative siblings of type 1 diabetic children but offers no explanation for it. Because the difference between ICA-negative siblings and normal children is not apparent in young ages, it may be related to a defective growth of the $\beta$-cell mass as well as to an abnormal maturation of insulin secretion. We speculate that its nature may be independent from immune-mediated events.

\section{Acknowledgments}

The authors wish to acknowledge Jean-Louis Chaussain for supporting this work, the nurses of Pediatric Endocrinology for their dedication to this prospective work, the children and their families for participating in this study, José Timsit for helpful discussions, Marc Roger for the determination of plasma insulin, and Georges Eisenbarth for duplicating some of the plasma insulin measurements.

This work was supported by a grant from Institut Electricité Santé and by Novo Nordisk (Alfediam).

\section{References}

1. LaPorte, R. E., H. A. Fishbein, A. L. Drash, L. H. Kuller, B. B. Schneider, T. J. Orchard, and D. K. Wagener. 1981. The Pittsburgh insulin-dependent diabetes mellitus (IDDM) registry: the incidence of insulin-dependent diabetes in Allegheny County, Pennsylvania (1965-1976). Diabetes. 30:279-284.

2. Levy-Marchal, C., L. Papoz, C. de Beaufort, J. Doutreix, V. Froment, J. Voirin, A. Collignon, B. Garros, Y. Scherlet, and P. Czernichow. 1990. Incidence of juvenile type I (insulin-dependent) diabetes mellitus in France. Diabetologia. 33:465-469.

3. Castano, L., and G. S. Eisenbarth. 1990. Type-I diabetes: a chronic autoimmune disease of human, mouse and rat. Annu. Rev. Immunol. 8:647-679.

4. Tarn, A. C., J. M. Thomas, B. M. Dean, D. Ingram, G. Schwartz, G. F. Botazzo, and E. A. M. Gale. 1988. Predicting insulin-dependent diabetes. Lancet. i:845-850.

5. Ziegler, A. G., R. Dumont Herskowitz, R. A. Jackson, J. S. Soeldner, and G. S. Eisenbarth. 1990. Predicting type I diabetes. Diabetes Care. 13:762-775.

6. Riley, W. J., N. K. Maclaren, J. Krishner, R. P. Spillar, J. H. Silverstein D. A. Schatz, S. Schwartz, J. Malone, S. Shah, C. Vadheim, and J. I. Rotter. 1990. A prospective study of the development of diabetes in relatives of patients with insulin-dependent diabetes. N. Engl. J. Med. 323:1167-1172.
7. Barbosa, J., R. A. Cohen, B. Chavers, A. F. Michael, M. Steffes, B. Hoogwerf, E. Szalapski, and M. Mauer. 1980. Muscle extracellular membrane immunofluorescence and HLA as possible markers of prediabetes. Lancet. ii:330-333.

8. Ginsberg-Fellner, F., M. J. Dobersen, M. E. Witt, E. J. Rayfield, P. Rubinstein, and A. L. Notkins. 1982. HLA antigens, cytoplasmic islet cell antibodies, and carbohydrate tolerance in families of children with insulin-dependent diabetes mellitus. Diabetes. 31:292-298.

9. Rosenbloom, A. L., R. Bianchi, and F. T. W. Chin. 1973. Screening for glucose intolerance in siblings of children with diabetes. Metab. Clin. Exp. 22:351-354.

10. Orchard, T. J., D. K. Wagener, B. S. Rabin, R. E. LaPorte, D. Cavender, L. H. Kuller, A. L. Drash, and D. J. Becker. 1986. Glucose tolerance in siblings of type I diabetic patients: relationship to HLA status. Diabetologia. 29:39-46.

11. Beer, S. F., D. A. Heaton, K. G. M. M. Alberti, D. A. Pyke, and R. D. G. Leslie. 1990. Impaired glucose tolerance precedes but does not predict insulin-dependent diabetes mellitus: a study of identical twins. Diabetologia. 33:497-502.

12. Thomson, G., W. P. Robinson, M. K. Kuhner, S. Joe, M. J. MacDonald, J. L. Gottschall, J. Barbosa, S. S. Rich, J. Bertrams, M. P. Baur, J. Partanen, B. D. Tait, E. Schober, W. R. Mayr, J. Ludvigsson, B. Lindblom, N. R. Farid, C. Thompson, and I. Deschamps. 1988. Genetic heterogeneity, modes of inheritance, and risk estimates for a joint study of Caucasians with insulin-dependent diabetes mellitus. Am. J. Hum. Genet. 43:799-816.

13. Simpson, R. G., A. Benedetti, G. M. Grodsky, J. H. Karam, and P. H. Forsham. 1968. Early phase of insulin release. Diabetes. 17:684-692.

14. Cerasi, E., and R. Luft. 1967. "What is inherited-what is added." Hypothesis for the pathogenesis of diabetes mellitus. Diabetes. 16:615-627.

15. Johnston, C., P. Raghu, D. K. McCulloch, J. C. Beard, W. K. Ward, L. J. Klaff, B. McKnight, R. N. Bergman, and J. P. Palmer. 1987. $\beta$-cell function and insulin sensitivity in nondiabetic HLA-identical siblings of insulin-dependent diabetics. Diabetes. 36:829-837.

16. McCulloch, D., L. J. Klaff, S. E. Kahn, S. L. Schoenfeld, C. J. Greenbaum, R. S. Mauseth, E. A. Benson, G. T. Nepom, L. Shewey, and J. P. Palmer. 1990 Nonprogression of subclinical $\beta$-cell dysfunction among first-degree relatives of IDDM patients. 5-yr follow-up of the Seattle family study. Diabetes. 39:549-556.

17. Rich, S. S., S. S. Panter, F. C. Goetz, B. Hedlund, and J. Barbosa. 1991 Shared genetic susceptibility of type I (insulin-dependent) and type 2 (non-insulin-dependent) diabetes mellitus: contribution of HLA and haptoglobin. Diabetologia. 34:350-355.

18. Allen, C., M. Palta, and D. J. D'Alessio. 1991. Risk of diabetes in siblings and other relatives of IDDM subjects. Diabetes. 40:831-836.

19. Julier, C., R. N. Hyer, J. Davies, F. Merlin, P. Soularue, L. Briant, G. Cathelineau, I. Deschamps, J. I. Rotter, P. Froguel, C. Boitard, J. I. Bell, and M. Lathrop. 1991. Insulin-IGF2 region on chromosome 11p encodes a gene implicated in HLA-DR4-dependent diabetes susceptibility. Nature (Lond.). 354:155159.

20. Srikanta, S., O. P. Ganda, A. Rabizadeh, J. S. Soeldner, and G. S. Eisenbarth. 1985. First-degree relatives of patients with type I diabetes mellitus. Isletcell antibodies and abnormal insulin secretion. N. Engl. J. Med. 313:461-464.

21. Amiel, S. A., R. S. Sherwin, D. C. Simonson, A. A. Lauritano, and W. V. Tamborlane. 1986. Impaired insulin action in puberty. A contributing factor to poor glycemic control in adolescents with diabetes. N. Engl. J. Med. 315:215219. 
22. Bloch, C. A., P. Clemons, and M. A. Sperling. 1987. Puberty decreases insulin sensitivity. J. Pediatr. 110:481-487.

23. Caprio, S., G. Plewe, M. P. Diamond, D. C. Simonson, S. D. Boulware, R. S. Sherwin, and W. V. Tamborlane. 1989. Increased insulin secretion in puberty: a compensatory response to reductions in insulin sensitivity. J. Pediatr. 114:963-967.

24. Cutfield, W. S., R. N. Bergman, R. K. Menon, and M. A. Sperling. 1990. The modified minimal model: application to measurement of insulin sensitivity in children. J. Clin. Endocrinol. \& Metab. 70:1644-1650.

25. Bleich, D., R. A. Jackson, J. S. Soeldner, and G. S. Eisenbarth. 1990. Analysis of metabolic progression to type I diabetes in ICA + relatives of patients with type I diabetes. Diabetes Care. 13:111-118.

26. Dupin, H., and Membres de la Commission des Etudes de Recherche sur l'Alimentation et la Nutrition. 1981. Apports nutritionnels conseillés pour la population française. Techniques et Documentation, Paris.

27. Boitard, C., E. Bonifacio, G. F. Bottazzo, H. Gleichmann, and J. Molenaar. 1988. Immunology and diabetes workshop: report on the third internationa (stage 3) workshop on the standardisation of cytoplasmic islet cell antibodies. Diabetologia. 31:451-452.

28. Castano, L., C. Boitard, and P. F. Bougnères. 1988. Cyclosporin A suppresses insulin autoantibodies and heterologous insulin antibodies in type I diabetic children. Diabetes. 37:1048-1052.

29. National Diabetes Data Group. 1979. Classification and diagnosis of diabetes mellitus and other categories of glucose intolerance. Diabetes. 28:10391057.

30. Fontbonne, A., G. Papoz, and E. Eschwege. 1986. Drug sales data and prevalence of diabetes in France. Rev. Epidemiol. Med. Soc. Sante Publique 34:100-105.

31. Hartling, S. G., F. Lindgren, G. Dahlqvist, B. Persson, and C. Binder.
1989. Elevated proinsulin in healthy siblings of IDDM patients independent of HLA identity. Diabetes. 38:1271-1274.

32. Todd, J. A., and S. C. Bain. 1992. A practical approach to identification of susceptibility genes for IDDM. Diabetes. 41:1029-1034.

33. Lindgren, F., G. Dahlquist, S. Efendic, E. Moller, B. Persson, B. Thalme, and M. Landlin Olsson. 1987. Glucose-induced insulin response and insulin sensitivity is not related to HLA-type but to age in young siblings of Type I (insulin-dependent) diabetic patients. Diabetologia. 30:727-732.

34. Sidhu, M., D. Crook, I. F. Godsland, C. Walton, V. Wynn, and M. F. Oliver. 1992. Inverse relationship between serum $\operatorname{Lp}(\mathrm{a})$ levels and first-phase insulin secretion. Diabetes. 41:1341-1345.

35. Karjalainen, J., P. Samela, J. Ilonen, H.-M. Surcel, and M. Knip. 1989. A comparison of childhood and adult type I diabetes mellitus. N. Engl. J. Med. 320:881-886.

36. Caillat-Zucman, S., H.-J. Garchon, J. Timsit, R. Assan, C. Boitard, I. Djilali-Saiah, P. Bougnères, and J.-F. Bach. 1992. Age-dependent HLA genetic heterogeneity of type I insulin-dependent diabetes mellitus. J. Clin. Invest. 90:2242-2250.

37. Bougnères, P. F., P. Landais, A. M. Mairesse, J. P. Jais, J. Jos, J. Peyraud, M. C. Wieliczko, P. Chavoix, P. Garandeau, D. Asensi, Y. Ithier, V. Rouland, T. Mazoyer, F. Leturca, and E. Raynaud. 1993. Improvement of diabetic control and acceptability of a three-injection insulin regimen in diabetic adolescents. A multicenter controlled study. Diabetes Care. 16:94-102.

38. Betterle, C., F. Zanette, A. Tiengo, and A. Trevisan. 1982. Five-year follow-up of non diabetes with islet-cell antibodies. Lancet. i:284-285.

39. Smith, C. P., A. J. K. Williams, J. M. Thomas, H. R. Archibald, V. D. Algar, G. F. Botazzo, E. A. M. Gale, and M. O. Savage. 1988. The pattern of basal and stimulated insulin responses to intravenous glucose in first degree relatives of type I (insulin-dependent) diabetic children and unrelated adults aged 5 to 50 years. Diabetologia. 31:430-434. 